\title{
THE EFFECT OF THE ANTIOXIDANT DRUG U-74389G ON ALBUMIN LEVELS DURING ISCHEMIA REPERFUSION INJURY IN RATS
}

\author{
C. Tsompos ${ }^{1}$, C. Panoulis ${ }^{2}$, K. Toutouzas ${ }^{3}$, A. Triantafyllou ${ }^{4}$, G. Zografos ${ }^{5}$ and A. Papalois ${ }^{6}$ \\ 1 Department of Obstetrics \& Gynecology, Mesologi County Hospital, Etoloakarnania, Greece \\ 2Department of Obstetrics \& Gynecology, \\ Aretaieion Hospital, Athens University, Attiki, Greece \\ ${ }^{3}$ Department of Surgery, Ippokrateion General Hospital, Athens University, Attiki, Greece \\ ${ }^{4}$ Department of Biologic Chemistry, Athens University, Attiki, Greece \\ ${ }^{5}$ Department of Surgery, Ippokrateion General Hospital, Athens University, Attiki, Greece \\ ${ }^{6}$ Experimental Research Centre ELPEN Pharmaceuticals
}

Summary. This experimental study examined the effect of the antioxidant drug $\mathrm{U}-74389 \mathrm{G}$ on a rat model and particularly in a liver ischemia - reperfusion protocol. The effects of that molecule were studied biochemically using blood mean albumin levels. 40 rats of mean weight $231.875 \mathrm{~g}$ were used in the study. Albumin levels were measured at 60th min of reperfusion (groups $A$ and $C$ ) and at 120th min of reperfusion (groups B and D). The drug U-74389G was administered only in groups C and D. U-74389G administration significantly decreased the predicted albumin levels by $3.63 \% \pm 0.87 \%(p=0.0001)$. Reperfusion time non-significantly increased the predicted albumin levels by $0.72 \% \pm 1.04 \%$ ( $p=0.4103)$. However, U-74389G administration and reperfusion time together significantly decreased the predicted albumin levels by $2.02 \% \pm 0.54 \%(p=0.0005)$. U-74389G administration whether it interacted or not with reperfusion time has significant decreasing short - term effects on albumin levels. It seems that the antioxidant capacity is associated with albumin catabolism.

Key words: ischemia, U-74389G, albumin level, reperfusion 


\section{INTRODUCTION}

$\mathrm{P}$ ermanent or transient damage with serious implications on adjacent organs and systems may be due to tissue ischemia - reperfusion (IR). The use of U-74389G in IR has been a challenge for many years. However, although the progress was significant, several practical questions have not been clarified. They include: a) how potent U-74389G should be; b) when should it be administered; and c) at what optimal dose U-74389G should be administered. The promising effect of U-74389G in tissue protection has been noted in several IR studies. U-74389G or also known as 21-[4-(2,6-di-1-pyrrolidinyl-4-pyrimidinyl)1-piperazinyl]-pregna-1,4,9(11)-triene-3,20-dione maleate salt is an antioxidant which prevents both arachidonic acid-induced and iron-dependent lipid peroxidation1. It protects against IR injury in animal organs such as heart, liver and kidney models. These membrane-associated antioxidants are particularly effective in preventing permeability changes in brain microvascular endothelial cells monolayers [2]. A meta-analysis of 20 published seric variables, coming from the same experimental settings, tried to provide a numeric evaluation of the U-74389G efficacy at the same endpoints (Table 1). Several publications addressed trials of other similar antioxidant molecules to which the studied molecule U-74389G belongs to.

The aim of this experimental study was to examine the effect of the antioxidant drug "U-74389G" on rat model and particularly in a generalized ischemia - reperfusion (IR) protocol. The effects of that molecule were studied by measuring blood mean albumin levels.

\section{MATERIAL AND METHODS}

\section{Animal preparation}

This basic experimental research was licensed by Veterinary Address of East Attiki Prefecture under 3693/12-11-2010 \& 14/10-1-2012 decisions. All consumables, equipment and substances, were a grant of Experimental Research Centre of ELPEN Pharmaceuticals Co. Inc. S.A. at Pikermi, Attiki. Accepted standards of human animal care were adopted for Albino female Wistar rats. 7 days pre-experimental normal housing included ad libitum diet in laboratory. Prenarcosis of animals preceded of continuous intra-experimental general anesthesia [3-6], oxygen supply, electrocardiogram and acidometry. Post-experimental euthanasia did not permitted awakening and preservation of the animals. Rats were randomly delivered to four experimental groups by 10 animals in each one, using following protocols of IR: Ischemia for $45 \mathrm{~min}$ followed by reperfusion for $60 \mathrm{~min}$ (group A); ischemia for 45 min followed by reperfusion for $120 \mathrm{~min}$ (group B); ischemia for 45 min followed by immediate U-74389G intravenous (IV) administration and reperfusion for 60 min (group C); ischemia for 45 min followed by immediate U-74389G IV administration

C. Tsompos et al. 


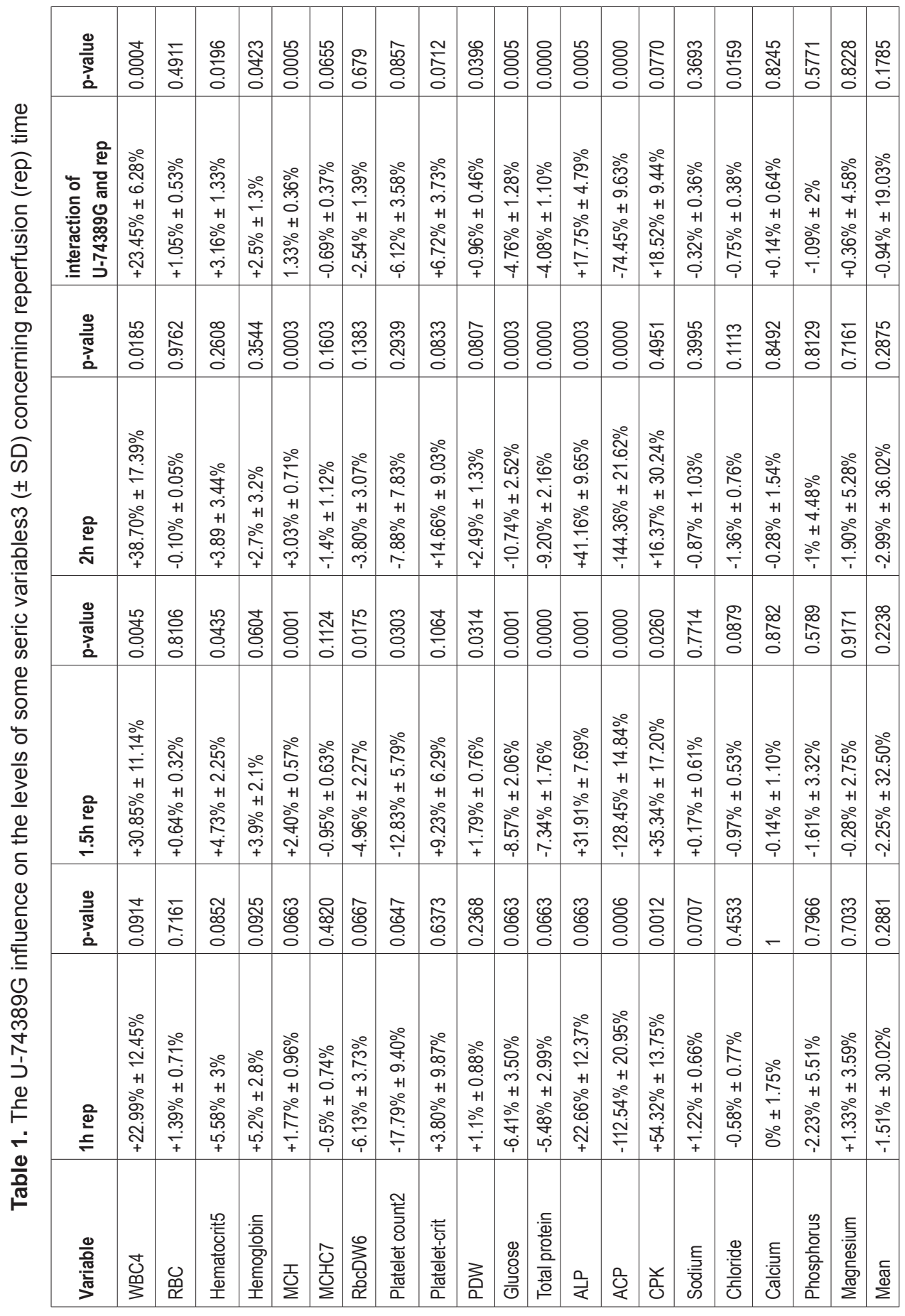

The effect of the antioxidant drug... 
and reperfusion for $120 \mathrm{~min}$ (group D). The dose of U-74389G was $10 \mathrm{mg} / \mathrm{kg}$ body mass of animals. Ischemia was caused by laparotomic clamping inferior aorta over renal arteries with forceps for $45 \mathrm{~min}$. Reperfusion was induced by removing the clamp and re-establishing inferior aorta patency. U-74389G was administered at the time of reperfusion; through catheterized inferior vena cava. The albumin levels were determined at $60^{\text {th }}$ min of reperfusion (for $A$ and $C$ groups) and at $120^{\text {th }}$ min of reperfusion (for $B$ and $D$ groups). Fourty female Wistar albino rats were used (mean weight $231.875 \mathrm{~g}$ [Standard Deviation (SD): $36.59703 \mathrm{~g}$ ], with minimum weight $165 \mathrm{~g}$ and maximum weight $320 \mathrm{~g}$. Rats' weight could be potentially a confusing factor, e.g. more obese rats to have higher albumin levels. This assumption was also investigated.

\section{Control groups}

20 control rats of mean weight $252.5 \mathrm{~g}$ [SD: $39.31988 \mathrm{~g}$ ] experienced ischemia for 45 min followed by reperfusion.

\section{Group A}

Reperfusion which lasted 60 min concerned 10 controls rats of mean weight 243 g [SD: $45.77724 \mathrm{~g}$ ] and mean albumin levels $3.55 \mathrm{~g} / \mathrm{dL}$ [SD: $0.3308239 \mathrm{~g} / \mathrm{dL}$ ] (Table 2).

\section{Group B}

Reperfusion which lasted 120 min concerned 10 controls rats of mean weight 262 $\mathrm{g}$ [SD: $31.10913 \mathrm{~g}$ ] and mean albumin levels $3.83 \mathrm{~g} / \mathrm{dL}$ [SD: $0.3917198 \mathrm{~g} / \mathrm{dL}$ ] (Table 2).

Lazaroid (L) group

20 rats of mean weight $211.25 \mathrm{~g}$ [SD: $17.53755 \mathrm{~g}$ ] experienced ischemia for $45 \mathrm{~min}$ followed by reperfusion in the beginning of which $10 \mathrm{mg} \mathrm{U}-74389 \mathrm{G} / \mathrm{kg}$ body weight were IV administered.

\section{Group C}

Reperfusion which lasted 60 min concerned $10 \mathrm{~L}$ rats of mean weight $212.5 \mathrm{~g}$ [SD: $17.83411 \mathrm{~g}$ ] and mean albumin levels $3.51 \mathrm{~g} / \mathrm{dL}$ [SD: $0.213177 \mathrm{~g} / \mathrm{dL}$ ] (Table 2).

\section{Group D}

Reperfusion which lasted 120 min concerned $10 \mathrm{~L}$ rats of mean weight $210 \mathrm{~g}$ [SD: $18.10463 \mathrm{~g}$ ] and mean albumin levels $3.51 \mathrm{~g} / \mathrm{dL}$ [SD: $0.2282786 \mathrm{~g} / \mathrm{dL}$ ] (Table 2).

Table 2. Weight and albumin mean* levels and SD of groups

\begin{tabular}{|l|l|l|l|}
\hline Groups & Variable & Mean & SD \\
\hline A & Weight & $243 \mathrm{~g}$ & $45.77724 \mathrm{~g}$ \\
\hline A & Albumin & $3.55 \mathrm{~g} / \mathrm{dL}$ & $0.3308239 \mathrm{~g} / \mathrm{dL}$ \\
\hline B & Weight & $262 \mathrm{~g}$ & $31.10913 \mathrm{~g}$ \\
\hline B & Albumin & $3.83 \mathrm{~g} / \mathrm{dL}$ & $0.3917198 \mathrm{~g} / \mathrm{dL}$ \\
\hline C & Weight & $212.5 \mathrm{~g}$ & $17.83411 \mathrm{~g}$ \\
\hline C & Albumin & $3.51 \mathrm{~g} / \mathrm{dL}$ & $0.213177 \mathrm{~g} / \mathrm{dL}$ \\
\hline D & Weight & $210 \mathrm{~g}$ & $18.10463 \mathrm{~g}$ \\
\hline D & Albumin & $3.51 \mathrm{~g} / \mathrm{dL}$ & $0.2282786 \mathrm{~g} / \mathrm{dL}$ \\
\hline
\end{tabular}




\section{Statistical analysis}

Every weight and albumin level group was compared with each other by statistical standard t-tests (Table 3). Any significant difference among albumin levels, was investigated whether owed in any potent significant weight one. The application of generalized linear models $(\mathrm{glm})$ with dependant variable the albumin levels was followed. The 3 independent variables were the U-74389G or no drug administration, the reperfusion time and both variables in combination. Inserting the rats' weight also as an independent variable at glm analysis, a very significant relation resulted in $(p=0.0206)$, so as to further investigation was needed. The predicted albumin values, adjusted for rats' weight were calculated and are depicted at table 5. Afterwards, every predicted albumins level group was compared with each other by statistical standard t-tests (Table 6). The application of glm with dependant variable the predicted albumins levels was followed. The 3 independent variables were again the U-74389G or no drug administration, the reperfusion time and both variables in combination.

Table 3. Statistical significance of mean values difference for groups (DG) after statistical standard t test application.

\begin{tabular}{|l|l|l|l|}
\hline DG & Variable & Difference & p-value \\
\hline A-B & Weight & $-19 \mathrm{~g}$ & 0.2423 \\
\hline A-B & Albumin & $-0.28 \mathrm{~g} / \mathrm{dL}$ & 0.1189 \\
\hline A-C & Weight & $30.5 \mathrm{~g}$ & 0.0674 \\
\hline A-C & Albumin & $0.04 \mathrm{~g} / \mathrm{dL}$ & 0.7239 \\
\hline A-D & Weight & $33 \mathrm{~g}$ & 0.0574 \\
\hline A-D & Albumin & $0.04 \mathrm{~g} / \mathrm{dL}$ & 0.7995 \\
\hline B-C & Weight & $49.5 \mathrm{~g}$ & 0.0019 \\
\hline B-C & Albumin & $0.32 \mathrm{~g} / \mathrm{dL}$ & 0.0560 \\
\hline B-D & Weight & $52 \mathrm{~g}$ & 0.0004 \\
\hline B-D & Albumin & $0.32 \mathrm{~g} / \mathrm{dL}$ & 0.0847 \\
\hline C-D & Weight & $2.5 \mathrm{~g}$ & 0.7043 \\
\hline C-D & Albumin & $0 \mathrm{~g} / \mathrm{dL}$ & $01 / 01 / 00$ \\
\hline
\end{tabular}

\section{RESULTS}

The first glm resulted in: U-74389G administration non-significantly decreased the albumin levels by $0.18 \mathrm{~g} / \mathrm{dL}[-0.3780228 \mathrm{~g} / \mathrm{dL}-0.0180228 \mathrm{~g} / \mathrm{dL}](\mathrm{p}$ $=0.0736)$. This finding was in accordance with the results of standard t-test $(p=$ 0.0929). Reperfusion time non-significantly increased the albumins levels by $0.14 \mathrm{~g} /$ $\mathrm{dL}[-0.0614782 \mathrm{~g} / \mathrm{dL}-0.3414782 \mathrm{~g} / \mathrm{dL}](\mathrm{p}=0.1676)$, also in accordance with standard t-test $(p=0.1770)$. However, U-74389G administration and reperfusion time together significantly decreased the albumin levels by $0.0981818 \mathrm{~g} / \mathrm{dL}[-0.2185575$ 
$\mathrm{g} / \mathrm{dL}-0.0221939 \mathrm{~g} / \mathrm{dL}](\mathrm{p}=0.1069)$. Reviewing the above and table 3 , table 4 sums up concerning the alteration influence of U-74389G in connection with reperfusion time. The second glm resulted in: U-74389G administration significantly decreased the predicted albumin levels by $0.1310917 \mathrm{~g} / \mathrm{dL}[-0.1930275 \mathrm{~g} / \mathrm{dL}--0.0691559 \mathrm{~g} /$ $\mathrm{dL}](\mathrm{p}=0.0001)$. This finding was in accordance with the results of standard t-test $(p=0.0002)$. Reperfusion time non-significantly increased the predicted albumins levels by $0.0262184 \mathrm{~g} / \mathrm{dL}[-0.0487167 \mathrm{~g} / \mathrm{dL}-0.1011534 \mathrm{~g} / \mathrm{dL}](p=0.4831)$, also in accordance with standard t-test $(p=0.3375)$. However, U-74389G administration and reperfusion time together significantly decreased the predicted albumins levels by $0.0729491 \mathrm{~g} / \mathrm{dL}[-0.1116138 \mathrm{~g} / \mathrm{dL}--0.0342844 \mathrm{~g} / \mathrm{dL}](p=0.0005)$. Reviewing the above and table 6 , the tables 7 and 8 sum up concerning the alteration influence of U-74389G in connection with reperfusion time.

Table 4. The decreasing influence of U-74389G in connection with reperfusion time

\begin{tabular}{|l|l|l|l|l|}
\hline Decrease & $95 \%$ c. in. & Reperfusion time & t-test, $\mathrm{p}$-values & glm, $\mathrm{p}$-values \\
\hline $0.04 \mathrm{~g} / \mathrm{dL}$ & $-0.3014689 \mathrm{~g} / \mathrm{dL}-0.221469 \mathrm{~g} / \mathrm{dL}$ & $1 \mathrm{~h}$ & 0.7239 & 0.7516 \\
\hline $0.18 \mathrm{~g} / \mathrm{dL}$ & $-0.3780228 \mathrm{~g} / \mathrm{dL}-0.0180228 \mathrm{~g} / \mathrm{dL}$ & $1.5 \mathrm{~h}$ & 0.0929 & 0.0736 \\
\hline $0.32 \mathrm{~g} / \mathrm{dL}$ & $-0.6212136 \mathrm{~g} / \mathrm{dL}-0.0187864 \mathrm{~g} / \mathrm{dL}$ & $2 \mathrm{~h}$ & 0.0847 & 0.0386 \\
\hline$-0.14 \mathrm{~g} / \mathrm{dL}$ & $-0.0614782 \mathrm{~g} / \mathrm{dL}-0.3414782 \mathrm{~g} / \mathrm{dL}$ & reperfusion time & 0.1770 & 0.1676 \\
\hline $0.0981818 \mathrm{~g} / \mathrm{dL}$ & $-0.2185575 \mathrm{~g} / \mathrm{dL}-0.0221939 \mathrm{~g} / \mathrm{dL}$ & interaction & - & 0.1069 \\
\hline
\end{tabular}

Table 5. Mean predicted albumin values* adjusted for weight and SD of groups

\begin{tabular}{|l|l|l|}
\hline Groups & Mean & SD \\
\hline A & $3.635355 \mathrm{~g} / \mathrm{dL}$ & $0.1454794 \mathrm{~g} / \mathrm{dL}$ \\
\hline B & $3.695737 \mathrm{~g} / \mathrm{dL}$ & $0.0988641 \mathrm{~g} / \mathrm{dL}$ \\
\hline C & $3.538427 \mathrm{~g} / \mathrm{dL}$ & $0.0566764 \mathrm{~g} / \mathrm{dL}$ \\
\hline D & $3.530482 \mathrm{~g} / \mathrm{dL}$ & $0.0575361 \mathrm{~g} / \mathrm{dL}$ \\
\hline
\end{tabular}

Table 6. Statistical significance of mean values difference for groups (DG) after statistical standard t test application.

\begin{tabular}{|l|l|l|}
\hline DG & Difference & p-value \\
\hline A-B & $-0.0603818 \mathrm{~g} / \mathrm{dL}$ & 0.2423 \\
\hline A-C & $0.0969282 \mathrm{~g} / \mathrm{dL}$ & 0.0674 \\
\hline A-D & $0.1048733 \mathrm{~g} / \mathrm{dL}$ & 0.0574 \\
\hline B-C & $0.15731 \mathrm{~g} / \mathrm{dL}$ & 0.0019 \\
\hline B-D & $0.1652551 \mathrm{~g} / \mathrm{dL}$ & 0.0004 \\
\hline C-D & $0.0079451 \mathrm{~g} / \mathrm{dL}$ & 0.7042 \\
\hline
\end{tabular}


Table 7. The decreasing influence of U-74389G in connection with reperfusion time.

\begin{tabular}{|l|l|l|l|l|}
\hline Decrease & $95 \% \mathrm{c}$. in & Reperfusion time & t-test, $\mathrm{p}$-values & glm, $\mathrm{p}$-values \\
\hline$-0.0969282 \mathrm{~g} / \mathrm{dL}$ & $-0.200656 \mathrm{~g} / \mathrm{dL}-0.0067996 \mathrm{~g} / \mathrm{dL}$ & $1 \mathrm{~h}$ & 0.0674 & 0.0653 \\
\hline$-0.13109165 \mathrm{~g} / \mathrm{dL}$ & $-0.1930275 \mathrm{~g} / \mathrm{dL}-0.0691559 \mathrm{~g} / \mathrm{dL}$ & $1.5 \mathrm{~h}$ & 0.0002 & 0.0001 \\
\hline$-0.1652551 \mathrm{~g} / \mathrm{dL}$ & $-0.2412508 \mathrm{~g} / \mathrm{dL}-0.0892594 \mathrm{~g} / \mathrm{dL}$ & $2 \mathrm{~h}$ & 0.0004 & 0.0002 \\
\hline$+0.0262184 \mathrm{~g} / \mathrm{dL}$ & $-0.0487167 \mathrm{~g} / \mathrm{dL}-0.1011534 \mathrm{~g} / \mathrm{dL}$ & reperfusion time & 0.3375 & 0.4831 \\
\hline$-0.0729491 \mathrm{~g} / \mathrm{dL}$ & $-0.1116138 \mathrm{~g} / \mathrm{dL}-0.0342844 \mathrm{~g} / \mathrm{dL}$ & interaction & - & 0.0005 \\
\hline
\end{tabular}

Table 8. The (\%) decreasing influence* of U-74389G in connection with reperfusion time.

\begin{tabular}{|l|l|l|l|}
\hline Decrease & \pm SD & Reperfusion time & p-values \\
\hline$-2.70 \%$ & $\pm 1.47 \%$ & $1 \mathrm{~h}$ & 0.0663 \\
\hline$-3.63 \%$ & $\pm 0.87 \%$ & $1.5 \mathrm{~h}$ & 0.0001 \\
\hline$-4.57 \%$ & $\pm 1.07 \%$ & $2 \mathrm{~h}$ & 0.0003 \\
\hline$+0.72 \%$ & $\pm 1.04 \%$ & reperfusion time & 0.4103 \\
\hline$-2.02 \%$ & $\pm 0.54 \%$ & interaction & 0.0005 \\
\hline
\end{tabular}

Results are expressed as Mean $\pm S D$ of the mean $\left({ }^{*} P<0.05, n=10\right)$

\section{DISCUSSION}

Ischemia may influence the albumin levels. Liepinsh E. et al. demonstrated7 that ischemic damage is significantly lower in the fed state compared with fasted state in Wistar and diabetic Goto-Kakizaki rats' hearts. Even overnight fasting could provoke and aggravate cardiovascular events and high-risk cardiovascular patients should avoid prolonged fasting periods. Abubakar S. et al. determined8 the mean serum albumin significantly higher by $45.67 \%$ in short-term first-ever acute stroke favourable outcome patients than those with unfavourable outcome $(p=0.0001)$. Patients that died had significantly lower serum albumin $(1.66 \mathrm{~g} / \mathrm{dl})$ than survivors $(p=0.0001)$. Serum albumin of $1.55 \mathrm{~g} / \mathrm{dL}$ has sensitivity of $100 \%$ and specificity of $61.5 \%$. Low admission serum albumin was an independent determinant of poor outcome. Herisson F. et al. found [9] neither difference nor correlation in admission baseline ischemia-modified albumin (IMA) levels within 4.5 hours of acute ischemic and hemorrhagic stroke onset patients. Consuegra-Sanchez L. et al. found the 30-day combined end point 1.48-fold $(p=0.017)$ and the 1-year mortality rate 1.78-fold $(p=0.028)$ significantly10 higher in patients with IMA levels > 93.3 U/ml obtained on admission compared with lower IMA or IMA as a general independent predictor patients presenting to the emergency department with typical acute chest pain. Polk J.D. et al. measured significantly higher cobalt-albumin binding assay (CABA) test values by 1.67 -fold in clinically diagnosed [11] intestinal ischemia patients, than control patients without intestinal ischemia $(p=$ 
0.0002). This resulted in a sensitivity of $100 \%$ and a specificity of $85.7 \%$ for the CABA test, making it a useful tool for risk stratification of intestinal ischemia. Dusek J. et al. used [12] a negative IMA marker as an aid to rule out acute coronary syndrome (ACS) in low risk symptomatic patients with non-diagnostic ECG and normal troponin. Worster $A$. et al. found likelihood ratios 1.35 and 0.98 for $I M A<$ and $>80 \mathrm{U} / \mathrm{mL}$ respectively within 6 hours after chest pain in order to predict [13] a serious cardiac outcome within the following 72 hours, suggesting IMA as a poor short term predictor of serious cardiac outcomes. Rafael Sadaba J. et al. reduced [14] the mean tissue perfusion of the upper limb by $15.38 \%(p=0.0005)$ using Technetium-99m human serum albumin after removal of the radial artery, but did not affect short term hand function. Steinbauer $M$. et al. enhanced [15] the half-life and antioxidant activity of nitroxides by their covalent binding to human serum albumin, resulting in polynitroxyl albumin (PNA) in an IR hamster dorsal skinfold chamber model. PNA in the dose $1 \%$ b.w. and to a lesser extent albumin effectively reduced post-ischemic microvascular perfusion failure, and tissue injury. Although free oxygen radical scavenging seems to be an underlying mechanism leading to the beneficial effects of PNA on IR injury, hemodilution and known radical scavenging properties of pure albumin contribute in part to the observed effects. Donaldson G.C. et al. explained why deaths from arterial disease are more prevalent in winters associating short-term falls in temperature [16] with significant and prolonged hemoconcentration and hypertension which produce significant increases in serum albumin and in mortalities from ischemic heart disease and cerebrovascular disease. Arend S.M. et al. found [17] similar significant decreases in serum albumin values within $24 \mathrm{~h}$ in heart patients both treated and control ones with nitroglycerin. Pollock D.M. et al. produced [18] a significant increase by 2.05 -fold nearly identical to those of atrial natriuretic factor (ANF) at $0.5 \mu \mathrm{g} / \mathrm{kg} / \mathrm{min}$ in glomerular filtration rate (GFR) administering $10 \mu \mathrm{g} / \mathrm{kg} / \mathrm{min}$ A68828 after acute renal IR failure compared with vehicle controls $(p<0.05)$. These results indicate that infusion of a reduced-size analogue of ANF, A68828ANF improves renal function in the immediate post-ischemic period in Sprague-Dawley rats. Tilton R.G. et al. decreased the rate19 of intravascular clearance of radiolabelled albumin by $36 \%$ and increased the mean transit time of the coronary vasculature by albumin approximately 1.875 -fold in ischemic hearts than control hearts from rabbits fed normal chow and 2-fold increase prior to ischemia in rabbits fed cholesterol for 2-3 weeks.

Also, albumin levels are perhaps influenced by U-74389G. Bagetta G. et al. studied20 the epileptogenic and neurodegenerative effects of dendrotoxin K (DTx$\mathrm{K})$, from Dendroaspis polylepsis, a specific blocker of a noninactivating, voltage-sensitive $\mathrm{K} \pm$ channel, after focal injection into one dorsal hippocampus in rats pretreated with the 21-aminosteriod U-74389G, a scavenger of free oxygen radicals. Administration of 35 pmol DTx-K elicited in all of the treated animals motor seizures and bilateral electrocortical (ECoG) discharges. Quantitation of hippocampal damage after 
$24 \mathrm{~h}$ revealed significant bilateral neuronal cell loss relative to the corresponding brain regions of rats injected with bovine serum albumin (300 ng). Systemic (i.p.) administration of U-74389G ( $5 \mathrm{mg} / \mathrm{kg}$ given $30 \mathrm{~min}$ beforehand) delayed the onset of motor and ECoG seizures and reduced the number of epileptogenic discharges typically observed in rats receiving an injection of DTx-K (35 pmol) alone. Similarly, this treatment prevented the damage inflicted to the hippocampus by the toxin. In conclusion, the present data support a role for free oxygen radicals in mediating hippocampal damage induced by DTX-K. Tasaka S. et al. attributed21 hyperoxic lung injury to oxygen radicals produced under hyperoxic conditions. They injected either vehicle or $10 \mathrm{mg} / \mathrm{kg}$ of U-74389G $30 \mathrm{~min}$ before the $90 \% \mathrm{O}_{2}$ exposure for $48 \mathrm{~h}$ and injected the same dose 12, 24, and $36 \mathrm{~h}$ later in guinea pigs. They measured the concentration ratio of 125l-labeled albumin in lung tissue and bronchoalveolar lavage (BALF) fluid compared with plasma (BALF/P and T/P respectively) as indexes of pulmonary endothelial damage.

\section{CONCLUSION}

U-74389G administration, whether it interacted or not with reperfusion time, has significant decreasing short - term effects on albumin levels. It is interesting to be investigated how the antioxidant capacity consumes albumins and into which metabolic pathways are involved, by further molecular studies.

Acknowledgment: This study was funded by Scholarship by the Experimental Research Center ELPEN Pharmaceuticals (E.R.C.E), Athens, Greece. The research facilities for this project were provided by the aforementioned institution.

\section{REFERENCES}

1. https://www.caymanchem.com/app/template/Product.vm/catalog/75860.

2. Fenglin Shi, Jennifer Cavitt, Kenneth L Audus. 21-aminosteroid and 2-(aminomethyl)chromans inhibition of arachidonic acid-induced lipid peroxidation and permeability enhancement in bovine brain microvessel endothelial cell monolayers. Free Radical Biology and Medicine, 19(3), 349-357 (1995).

3. Tsompos C, Panoulis C, Toutouzas K, Triantafyllou A, Zografos G, Papalois A. The effect of the antioxidant drug "U-74389G" on acid phosphatase levels during ischemia reperfusion injury in rats. Appl Med Res. 2016;2(1):1-5.

4. Tsompos C, Panoulis C, Toutouzas K, Triantafyllou A, Zografos G, Papalois A. The effect of the antioxidant drug "U-74389G" on white blood cells levels during hypoxia reoxygenation injury in rats. Asian Journal of Pharmacology and Toxicology. 2016;4(13): 22-32.

5. Tsompos C, Panoulis C, Toutouzas K, Zografos G, Papalois A. Acute Effect Of The Antioxidant Drug "U74389g" On Hematocrit Levels During Hypoxia and Reoxygenation Injury In Rats. Sci. Med. 2016;26(1): 15-21.

6. Tsompos C, Panoulis C, Toutouzas K, Triantafyllou A, Zografos G, Papalois A. The acute effect of the antioxidant drug "U-74389G" on red blood cell distribution width levels during hypoxia reoxygenation injury in rats. Folia Medica Пловдив 2015;57(3\&4):235-242.

The effect of the antioxidant drug... 
7. Tsompos C, Panoulis C, Toutouzas K, Triantafyllou A, Zografos G, Papalois A. The antioxidant drug "U-74389G" attenuates the mean corpuscular hemoglobin concentration levels during hypoxia reoxygenation injury in rats. JIRMEPS, 9(4): 158-163, 2016

8. Liepinsh E, Makrecka M, Kuka J, et al: The heart is better protected against myocardial infarction in the fed state compared to the fasted state. Metabolism. 2013 Oct 17. pii: S0026-0495(13)00298-9.

9. Abubakar S, Sabir A, Ndakotsu M, et al: Low admission serum albumin as prognostic determinant of 30-day case fatality and adverse functional outcome following acute ischemic stroke. Pan Afr Med J. 2013;14:53.

10. Herisson F, Delaroche O, Auffray-Calvier E, et al: Ischemia-modified albumin and heart fatty acidbinding protein: could early ischemic cardiac biomarkers be used in acute stroke management? J Stroke Cerebrovasc Dis. 2010 Jul-Aug;19(4):279-82.

11. Consuegra-Sanchez L, Bouzas-Mosquera A, Sinha MK, et al: Ischemia-modified albumin predicts short-term outcome and 1-year mortality in patients attending the emergency department for acute ischemic chest pain. Heart Vessels. 2008 May;23(3):174-80.

12. Polk JD, Rael LT, Craun ML, et al: Clinical utility of the cobalt-albumin binding assay in the diagnosis of intestinal ischemia. J Trauma. 2008 Jan;64(1):42-5.

13. Dusek J, Tichý M, Stásek J, et al: Ischemia-modified albumin: new marker of myocardial ischemia?. Cas Lek Cesk. 2005;144(5):295-7; discussion 297.

14. Worster A, Devereaux PJ, Heels-Ansdell D, et al: Capability of ischemia-modified albumin to predict serious cardiac outcomes in the short term among patients with potential acute coronary syndrome. CMAJ. 2005 Jun 21;172(13):1685-90.

15. Rafael Sadaba J, Conroy JL, Burniston M, et al: Effect of radial artery harvesting on tissue perfusion and function of the hand. Cardiovasc Surg. 2001 Aug;9(4):378-82.

16. Steinbauer M, Guba M, Büchner M, et al: Impact of polynitroxylated albumin (PNA) and tempol on ischemia/reperfusion injury: intravital microscopic study in the dorsal skinfold chamber of the Syrian golden hamster. Shock. 2000 Aug;14(2):163-8.

17. Donaldson GC, Robinson D, Allaway SL. An analysis of arterial disease mortality and BUPA health screening data in men, in relation to outdoor temperature. Clin Sci (Lond). 1997 Mar;92(3):261-8.

18. Arend SM, Bax JJ, Hermans J, et al: The short-term effect of intravenous nitroglycerin on haematocrit; an additional benefit in patients with myocardial ischaemia? Eur Heart J. 1994 Jan;15(1):114-9.

19. Pollock DM, Opgenorth TJ. Beneficial effect of the atrial natriuretic factor analog A68828 in postischemic acute renal failure. J Pharmacol Exp Ther. 1990 Dec;255(3):1166-9.

20. Tilton RG, Cole PA, Zions JD, et al: Increased ischemia-reperfusion injury to the heart associated with short-term, diet-induced hypercholesterolemia in rabbits. Circ Res. 1987 Apr;60(4):551-9.

21. Bagetta G, Palma E, Piccirilli S, et al: Seizures and hippocampal damage produced by dendrotoxin$\mathrm{K}$ in rats is prevented by the 21-aminosteroid U-74389G. Exp Neurol. 1997 Sep;147(1):204-10.

22. Tasaka S, Ishizaka A, Urano T, et al: Attenuation of hyperoxic lung injury by the 21 -aminosteroid U74389G. J Appl Physiol (1985). 1995 May;78(5):1635-41.

\section{Corresponding author:}

Tsompos Constantinos

Department of Obstetrics \& Gynecology

Mesologi County Hospital

Nafpaktou street

Mesologi 30200

Etoloakarnania

Greece

Tel: $00302631360237 \& 00306946674264$

Fax: 00302106811215

e-mail: Tsomposconstantinos@gmail.com 